\title{
CLAIMS FOR REPARATIONS AND DAMAGES RE- SULTING FROM VIOLATION OF NEUTRAL RIGHTS
}

\author{
William Gerald Downey, JR.*
}

International law is generally regarded as the law for the conduct of nations and is based upon the general assent of the members of the family of nations. Its sources are custom and lawmaking treaties. ${ }^{1}$

Neutrality is an integral chapter of international law. It has been defined as the condition of those states which in time of war take no part.in the contest, but continue pacific intercourse with the belligerents. ${ }^{2}$ It is usually considered under two headings, the first pertaining to the rights and duties of belligerent states and of the nationals thereof, and the second to the rights and duties of neutral states and of the nationals thereof. ${ }^{3}$ These rights and duties are correlative and neutrality can be violated by neutrals as well as belligerents.

It is the purpose of this article to discuss only the law pertaining to the rights of neutral states and the legal bases for claims by or against such neutral states for reparations and damages resulting from violations of such neutral rights. The remaining and. by far the greater part of the international law of neutrality will be discussed only when it affects the question of neutral rights or when it may serve as a defense for alleged violations of neutral rights.

It will be noted that wherever the word "damages" is used throughout this article it is to be distinguished from the term "reparations." Damages are usually included in demands for reparations, which is the term usually employed in referring to claims for violations of neutral rights and which embraces not only monetary compensation, but all the international acts which must be taken by the offending belligerent to restore the international prestige of the offended neutral. Wherever used herein,

* Major, JAGC, U. S. Army. Formerly Fellow in International Law, Catholic University of America, and Fellow in International Law, Georgetown University. Formerly Chief, International Law Branch, Judge Advocate General's Office, Department of the Army. The views expressed herein are those of the author and do not necessarily reflect the opinions of the Secretary of Defense, the Secretary of the Army, or of the Judge Advocate General of the Army. This article has been cleared for publication by the Office of the Secretary of Defense.

2 West Rand Central Gold Mining Co., Ltd., v. The King, [1905] 2 K. B. 39r; The S.S: Lotus, Permanent Court of International Justice, 2 Hudson, WORLd Court ReporTs I927-r932.20, 35 (I935); Frederick K. Nielsen, International Law Applied to Reclamattons 7 (1933); seé George Á. Finch, The Sources of Modern International. Law (1937), passim.

2 The Three Friends, 166 U. S. I (I897); T. J. Lawrence, The Principles of International Law 582 (7th ed. 1923). In the present writer's Axrerican Maritrme Neutrality Polrcy (1937), neutrality is defined "... as the continuation of $[$ the $] \ldots$ state of peace by one or more nations after the original status had been altered or changed by two or more warring or belligterent trations." "Presupposing the existence of a state of war, its primary purpose "is "to maintain the peace by keeping nations out of war and by defining the rights and duties of "warring and non-warring nations." Id. at r2. A footnote appended thereto states that in this definition warring nations are*considered as thọse which fight wițhout having made a declaration of war and belligerent'nations are those which fight after having made a declaration of war.

"EAWRENCE, op. cit. supra note 2, at 583-657. 
the term "damages" will refer only to the monetary compensation claimed by a neutral for violations of neutral rights resulting in injury to life and property.

An interesting recent example of the above stated distinction is to be found in the Panay case. In December 1937, Japanese naval aviators, in the course of military operations against the Chinese forces, bombed and sank the neutral U.S. S. Panay, which by virtue of certain treaty rights was legally patrolling a Chinese river. As a result of this illegal act of an arm of the Japanese Government, American lives were lost and United States property was destroyed. The Government of the United States protested this violation of its neutral rights and demanded reparations, including damages for the lives lost and property destroyed. The Government of Japan immediately acknowledged its responsibility for the bombing and apologized to the Government of the United States. By way of reparations Japan agreed to punish the aviators concerned ${ }^{4}$ and recalled and retired the admiral responsible for the bombing." The Government of Japan agreed to pay damages and several months later actually paid to the United States damages in the amount of $\$ 2,214,007.36$ as compensation for the injuries thereby inflicted. ${ }^{6}$

There are two general and basic neutral rights from which nearly all the specific and controversial rights of neutrals flow. These so-called rights are in reality only restatements of the principles of sovereignty. Reduced to their lowest common denominator, they state nothing more than the general rule that every state is the supreme authority within its own territory in time of peace as well as in time of war. Applied in the field of neutrality this age-old principle can be restated in the form of two rights as follows:

(I) the right to the freedom of neutral territory from belligerent attack; and

(2) the right to the freedom of neutral territory from belligerent use.

These basic rights will be discussed seriatim below.

It is a general principle of the law of neutrality that any violation of neutral rights constitutes an international tort, or as it is sometimes called, an international delinquency. ${ }^{7}$ Where such rights have been protected by international conventions, ${ }^{8}$ any violations of such conventional rights may also involve additional liability resulting from the breach of such conventional obligations. In addition to the Hague Conventions V and XIII there are many bilateral and multilateral treaties providing for the protection of neutral rights. ${ }^{9}$ As in domestic torts, an international tort involves an obligation on the part of the tortfeasor to make reparation. The great

'N. Y. Times, Dec. 26, 1937, 51, p. I, cols. I-4; 54, P. 3, cols. 7-8. See also, JosepH C. Grew, TEN YEARS IN JAPAN 232-242 (1944).

${ }^{5}$ Grew, op. cit. supro note 4 , at 236.

'Sec 32 As. J. INT'L L. 579 (1938); N. Y. Times, April 19, 1938, p. 10, col, x.

${ }^{2} 2$ Oppenheim, International Law $6 r_{4}$ (6th ed., Lauterpacht, 1944); I Georg Schwarzenatrger, A MaNual of International LAw 294 (1947).

'See Hague Conventions V (36 Stat. 2310, Trealy Ser. No. 540; 2 Malloy's Treatres 2290 (1910), and XIII ( 36 Stat. 2415; Treaty Scr. No. 545; 2 Malloy's Treat7es 2352 (1910)).

- See Francis Déak and Philip C. Jessup, a Collection of Neutrality laws. Regulattons and TrEatTes of Various Countries (x939) (two volumes) passim. 
difficulty in the international field lies in the fact that there are few courts available for the adjudication of international torts. Two courts which are available are the Permanent Court of Arbitration at the Hague and the International Court of Justice, formerly the Permanent Court of International Justice at the Hague. ${ }^{10}$

Acts in violation of the international law of neutrality are defined as those acts which are violations of the peaceful relationship between the neutral and belligerent states. Those acts would have entailed, prior to the outbreak of belligerency, the obligation to make reparations or pay damages according to the rules of customary or conventional international law as applied by an international arbitration tribunal. ${ }^{11}$ After the end of World War I the special arbitration tribunal between Germany and Portugal adopted this definition of acts in violation of international law. The tribunal.stated in its award that, while in point of time the responsibility of Germany for violations of neutral rights was limited to acts committed by Germany against allied or associated powers prior to their entrance into the war, it was immaterial, from the point of view of place of commission, whether the illegal acts were committed in Germany or in German occupied territory, whether they were committed against the neutral state or its subjects, or whether they were directed against the person or property of neutrals. ${ }^{12}$

x. The right to the freedom of neutral territory from belligerent attack. As neutral land, territorial waters, and air space are protected by this right, no acts of warfare of any kind may legally take place therein. ${ }^{13}$

A violation of this right may be handled in one of several ways. The neutral may protest through diplomatic channels as in the case of the Panay, supra. The neutral may by the use of armed force eject the tortfeasor who continues to violate neutral territory, waters or air space. ${ }^{14}$ However, such use of force may, and frequently has, led to war between the neutral and the offending belligerent. The German violations of the neutrality of Norway, Holland, Luxembourg, and Belgium in I940 led to war with those countries. On the other hand the German violation of the neutrality of Denmark and the military occupation of that country did not lead to war, nor did the British violation of the neutrality of Iceland and the "pacific"15 occupation of that country lead to war. Both of these violations of neutrality were justified on the grounds of military necessity. ${ }^{16}$ Concerning the

${ }^{10}$ For a short history of the Permanent Court of Arbitration, see Introduction to I JAMEs BRowN Scott, The Hague Court Reports iii-xvi (1916); for similar information about the Permanent Court of International Justice, see Mantey O. Hudson, THE World Count I921-1934 I-9 (4th ed., rev. I934).

${ }^{11}$ Goldenberg v. Germany, 1928, Special Arbitration Tribunal Between Rumania and Germany, $x$ Zeitschrift Für AusLandisches ÖFfentliches Recht UNd VölKerRecht [hereinafter Z. R. V.] 87, 93 (Germany 1928).

${ }_{12} 3$ Z. R. V. 5, 9-10 (Germany 1933).

132 Oppenhem, op. cit. supra note 7 , at $535-546$; see Article I of Hague Convention V, supra note 8.

${ }^{24}$ See Article ro of Hague Convention V, supra note 8, which provides: "The fact of a neutral Power resisting, even by force, attempts to violate its "neutrality cannot be regarded as a hostile act."

${ }^{15}$ See this writer's Revision of the Rules of Warfare, Proceedings of THE American Socikty in INTERNATIONAL LAW 102, 103 (1949).

${ }^{10}$ See Chronicle of International Events, "34 AMr:'J. INT'L I. 130 (1940). 
above mentioned violations of neutrality by Germany, $\mathrm{H}$. Lauterpacht wrote in 1940 :

It was not until Germany invaded Denmark and Norway in April and Belgium, Holland and Luxembourg in May 1940, that neutral status as such and the very independence of neutral nations as distinguished from particular neutral rights were ruthlessly violated by a lawless belligerent, and that other neutral states found themselves similarly and increasingly menaced from the same side. Nevertheless, in the first period of what some tended to describe as the second. World War; neutrality constituted a prominent feature of the situation. . . .17

- If the violation of neutrality is not considered justification for war-and the question of the relativity of war or peace is one for the offended neutral to decide in the light of all the circumstances ${ }^{18}$-the neutral state may claim reparations, and if physical injury has resulted, it may also claim damages. An interesting case, illustrative of this point; arose as the result of the accidental bombing by American planes of the Swiss city of Schaffhausen on April $i$, x944. The Secretary of State issued a statement on April 3 in which he stated:

I desire to express my own. and all Americans' deep regret over the tragic bombing by American planes of the Swiss city of Schaffhausen, ...

... a group of our bombers, due to a chain of events negating the extensive precautions which had been taken to prevent incidents of this character, mistakenly flew over and bombed Swišs. areas located on the north side of the Rhine.

... General Spaatz, accompanied by Ambassador Winant, has already called on the Șiss Charge d'Affaires in.London and expressed the deep regret of himself and the men in his command at the accidental bombing of Schaffhausen.

Naturally this Government will make appropriate reparations for the damage resulting from this unfortunate event in so far as that is humanly possible. ${ }^{10}$

On April to the American,Minister to Switzerland, Mr. Leland Harrison, transmitted a check for one million dollars to the:Government of Switzerland as the first installment on the payment for damages. ${ }^{20}$.

An important corollary of the right to the freedom of neutral territory from belligerent attack is the affirmative duty on the part of the neutral state to prevent violations of its neutrality by one belligerent to the injury of another as well as to protest and demand reparations in case of such violations. An interesting illustration of this corollary duty, and perhaps the leading case in the field, is the case of The General Armstrong, ${ }^{21}$ settled under the terms of the Convention of February 26, 1851 between Portugal and the United States ${ }^{22}$ by the then President of the French Republic, Louis Napoleon. The facts were briefly that Portugal remained neutral

${ }^{27} 2$ OPPENHEM, INTERNATIONAL LAW 505 (1940 ed. Lauterpacht).

${ }^{18} 7$ G. H. Hackworth, Digest OF International Law 368 (i943).

io yo Dep't State Bull. 314 (1944).

20.J. M. SPAjght, Air Power and War Rights 433 (3d ed. 1947).

${ }^{21} 2$ John Bassett Moore, History and Digest of the. International Arbitrations to Which the United States Has Been a Party ro94 (1898).

${ }^{22}$ Io Stat. 911, Treaty Ser. No. 290, 5 Trienties and Oţher IntzRnatzonal Acts of the Unitzid StATES OF AMERICs 929 (Miller ed. 1937). 
in the War of $18 \mathrm{rz}$ between the United States and Great Britain. In September I8I4, the American privateer, the General Armstrong, anchored in the neutral port of Fayal in the Portuguese Azores. A British squadron later entered the same port and "without respect for the rights of sovereignty and of neutrality ... [of Portugal] a bloody encounter took place between the Americans and the English," leading to the destruction of the American vessel..$^{23}$

Here was a clear violation by both belligerents of the right of Portugal to the inviolability of her territorial waters. The United States later claimed indemnity for the loss of the brig because of an alleged Portuguese failure to grant protection to the General Armstrong by a failure to assert Portuguese neutrality. President Napoleon stated in his arbitral award that:

... Captain Reid [the master of the General Armstrong] not having applied, in the beginning, for the intervention of the Neutral Sovereign, and having had recourse to arms for the purpose of repelling an unjust aggression of which he claimed to be the object, thus failed to respect the neutrality of the territory of the foreign sovereigni and released that sovereign from the obligation to afford him protection by any other means than that of a pacific intervention....24.

A somewhat later case involved the capture of the Confederate cruiser, Florida, by the U.S.S. Wachusett in the port of Bahia, Brazil, in October 1864. The Brazilian Government demanded reparations in the form of a public declaration by the United States that the United States was surprised by the illegal action of the commander of the Wachusett, rebuked and condemned it and regretted that it should have occurred; the immediate dismissal of the said commander, followed by the commencement of disciplinary action against him; a salute of 21 guns to be given in the port of the capital of Bahia by one of the United States war vessels; full liberty of the crew and all individuals who were aboard the Florida at the time of her capture; and the delivery of the Florida to the Government of Brazil. ${ }^{25}$

The Secretary of State acknowledged the responsibility of the United States and agreed to all the Brazilian reparations demands with the exception of the last. The return of the vessel to Brazil had become impossible because of the sinking of the captured vessel at Hampton Roads. The entire reply of the Government of the United States to the Brazilian demand for reparations was based exclusively on the ground that the act of the commander of the Wachusett in capturing the Florida within the territorial waters of Brazil was "an unauthorized, unlawful and indefensible exercise of the naval force of the United States, within a foreign country, in defiance of its established and duly recognized Government."26

These three cases, the Panay, The General Armstrong, and the Wachusett, clearly show the relationship between the neutral right to freedom from belligerent attack

\footnotetext{
${ }^{23}$ MoORe, op. cit. supra note $2 \mathrm{I}$, at rog4.

${ }^{24}$ Id. at 1095 .

25 7 John Bassett Moore, Digest of International Law rogo-togi (Ig06).

20 Id. at rogr.
} 
and the neutral duty to protect this freedom with all the means at its disposal. The Schaffhausen case explains the belligerent duty not to attack neutral territory and the belligerent obligation to make reparations and pay damages for injuries resulting from such an attack. All of the cited cases above pertain to violations of the law of neutrality and must not be confused with violations of the laws of war. A violation of neutrality is a breach of a duty and is an international tort, ${ }^{27}$ while a violation of the law of war is an international crime. ${ }^{28}$

The right to the freedom of neutral territory from belligerent attack does not extend to the real or personal property of a neutral state or individual in the zone of active military operations. ${ }^{29}$ In this type of case it is generally held that mere destruction of neutral property incidental to operations of war does not demand compensation or damages. ${ }^{30}$ Of course there is no question of reparations in such cases. The only question is whether international law imposes any duty upon a belligerent to give special protection to neutral property and the answer is that it does not. In answering a similar question arising out of the military occupation of Germany, the legal adviser of OMGUS stated:

It is a well settled rule of international law that no difference is to be made by belligerents between the treatment to be accorded to subjects of the enemy and to subjects of neutral states inhabiting the enemy country. The latter must share the fate of the population living in enemy territory; they are deemed to have acquired enemy character by being domiciled (i.e., resident) in enemy country and having thereby identified themselves with the enemy population. For this reason all measures which may legitimately be taken against the civil population of the enemy territory-including requisitions, contributions and punishments for hostile actions committed against the occcupant-may also be taken against them. ... Such resident subjects of neutral states have no better right than subjects of the enemy against the occupant for compensation for losses sustained in consequence of legitimate acts of war on the occupant's part.

It may be concluded, therefore, that international law imposes no duty upon an occupying power to give special protection to property located in an occupied area and owned by nationals of neutral nations resident therein. Such a duty, owing in particular cases, may, of course, be created by treaties or other international undertakings. ${ }^{31}$

The principle stated in the opinion of the legal adviser of OMGUS had been applied earlier in a case involving the arrest of a neutral person in occupied territory. The facts were that the claimant before the Greco-German Mixed Arbitral Tribunal had been arrested in Rumania during the German occupation in World War I on suspicion of concealing arms. He was detained for eight days and then released. Germany denied liability on the ground that the arrest could not be considered as falling within the meaning of the term "actes comises" of section 4, Annex to Articles 207-298 of the Treaty of Versailles. The Arbitral Tribunal held that the German

\footnotetext{
${ }^{27}$ See note 7 supra.

${ }^{23}$ See the Charter, Opinion, and Judgment of the International Military Tribunal at Nuremberg.

$2 "$ See SchwarzenBeRger, op. cit. supra note 7, at 296-300.

"Sce 2 OppenheIM, op. cit. supra note 7 , at 539.

' 12 SFlected Opinions OMGUS 72-73 (Apr. 1, 1948-Aug. 15, 1948).
} 
State was not responsible, because the occupying authorities were entitled to arrest any inhabitants of occupied territory, including neutral inhabitants thereof, suspected of concealing arms. The arrest was not per se an illegal act. The tribunal stated that in principle a neutral person wrongfully arrested would be entitled to compensation by reason of injury suffered in consequence of detention and that non-payment of such compensation would constitute an unlawful act under Section 4, Annex to Articles 297-298 of the Treaty of Versailles. However, eight days was not considered sufficient to constitute an unlawful arrest and the claimant was not considered likely to have been damaged in such a short period. ${ }^{32}$

It is almost generally held that the requisition of neutral property is legal provided full compensation is given. ${ }^{33}$ This is a right of a belligerent and is known as the ius angariae. The right of the freedom of neutral territory from belligerent attack has no applicability in cases arising under the izts angariae, or right of angary, which is a right of belligerents, in case of urgent necessity to detain, use or even destroy neutral property found within the territory of or occupied by the belligerent. The payment of compensation to the neutral is a necessary condition of such use. ${ }^{34}$ The application of this rule has usually arisen through the detention, use or destruction of neutral vessels temporarily in the ports of a belligerent, and the usual question arising therefrom is what is just compensation or indemnity to the neutral for the use of his property. In the Norwegian Claims case, which was tried before the Permanent Court of Arbitration at the Hague in 1922, the United States and Norway were the parties. There was a wide divergence of opinion between the parties as to the amount of indemnity due from the United States to Norway for Norwegian ships in the process of construction in the United States and requisitioned by the United States under the authority of an act of Congress which provided that just compensation must be paid. The Tribunal stated that:

Just compensation implies a complete restitution of the status quo ante, based, not upon future gains of the United States or other powers, but upon the loss of profits of the Norwegian owners as compared with other owners of similar property. ${ }^{35}$

The right to the freedom of neutral territory from attack does not extend to the two cases just discussed, but in World War I the question of aircraft in relation to the right of the inviolability of neutral territory first became of practical importance. The question arose as to the jurisdiction of a subjacent country over its air space. Because of their geographical situations, Switzerland and Holland faced many problems concerning this question. ${ }^{36}$ Each country claimed that its jurisdiction over its

32 Annual Digest of Public International Law Cases 1928-30 509 (Lauterpacht ed., i935).*.

${ }^{23}$ Schwarzenberger, op. cit. supta' note 7 , at" 298 .

${ }^{34}$ See Graham, Neturality and the World War, I7 Ax. J. INr'L L. 704, 7I5 (1923); see also U. S. Naval War College, International Law Discussions io4 (Ig03), wherein is set forth the United States rule. See also Draft Convention on Neutrality in Navial and Aerial Warfare, 33 AM. J. INT'L L. 359-385 (Supp. 1939).

at 2 Scorr, op. cit. supra note ro, at 73 .

so See Spalghr, op. cit. supra note 20 , at $420-460$. 
territory extended jusque ad coelum and therefore asserted the right to use necessary force to prevent the entrance of belligerent aircraft into neutral skies. ${ }^{37}$ Thus when belligerent aircraft passed over neutral territory without intending to land, they were fired at for the purpose of compelling them to do so. ${ }^{38}$ The belligerents, on the other hand, claimed the use of the skies over neutral territory and justified such use on the ground of military necessity.

It is proper, at this point, to discuss the defense of military necessity in relation to belligerent violations of neutral rights. The argument has been advanced that violations of neutral rights are justified on the grounds of military necessity and on the ground that the laws of neutrality are so inadequately defined as to be of little value in controlling belligerent actions.

It is important to determine here just what is military necessity and what are the international legal limitations on military necessity. In Field Manual 27-10, the Rules of Land Warfare, it is stated that one of three basic principles of warfare is:

The principle of military necessity, under which, subject to the principles of humanity and chivalry, a belligerent is justified in applying any amount and any kind of force to compel the complete submission of the enemy with the least possible expenditure of time, life, and money. ... ${ }^{38}$

Georg Schwarzenberger, the lecturer in international law at the University College, London, wrote that:

Military necessity . . . merely determines the farthest limits. to which considerations of military expediency may extend. Restrictions imposed by customary and conventional rules may more closely narrow the "reason of war" which is but the application to warfare of the principle that the end justifies the means most conducive to attaining it. ${ }^{40}$

Another famous publicist has recently stated that:

... In our days ... warfare is no longer regulated by usages only, but to a greater extent by laws-firm rules recognized either by international treaties or by general custom. These conventional and customary rules cannot be overruled by necessity. . . 41

Another writer has recently written that: .

The important question whether the laws of neutrality allow belligerent military aircraft to come and go in neutral jurisdiction was answered by the practice of $19 \mathrm{r}_{4}-\mathrm{rg} \mathrm{r} 8$ with a firm and unmistakable negative. The unanimity of the answer was remarkable. . . it Holland, Denmark, Sweden, Norway, Switzerland, Italy, Spain, Bulgaria, China, and Rumania, showed while they were all still neutral that they accepted the principle of prohibiting the entrance of belligerent aircraft into neutral skies and acknowledged the obligation to intern any belligerent aircraft violating this principle.

\footnotetext{
${ }^{37}$ U. S. Naval War College, International Law Struations roo-roị (1926).

${ }^{38} 2$ OPPENHEIM, op. cit. supta note 7 , at 586 .

${ }^{30}$ F.M. 27-Io, Rules of. LaNd Warfare I (1940).

${ }^{10}$ Schwarzenderger, op. cit. supra note 7 , at 262.

17 OPPENHeim, op. cit. supra note 7 , at I85.

"Spaighr, op. cit. supra note 20, at 420 .
} 
The practice of I9I4-Igr8 "created a rule of international law which must be regarded as being as firmly established as it is possible for such a rule to be."

. In commenting upon this customary rule of international law, which is certainly a limitation upon military necessity, $\mathrm{H}$. Lauterpacht remarked that:

The almost invariable practice of neutral states during the World War, coupled with the general acquiescence of belligerents, may be said to have established two customary rules: firstly, that belligerent aircraft mușt not enter the air space over neutral. territory in time of war; and secondly, that if they do, either intentionally or inadvertently, and are compelled to land, the neutral State must intern them.".

Customary international law became conventional international law through Article I4 of the Habana Convention on Maritime Neutrality which provides that the aircraft of belligerents shall not fly above the territory or territorial."waters of neutrals, if it is not in conformity with the regulations of the latter. ${ }^{45 .}$

- Writing in 1939, Green: Hackworth, then the legal adviser of the Department of State and now a Judge on the International Court of Justice; stated that:

It can now be said to be international law that belligerent war planes have no right to fly "into or through neutral jurisdiction. "The subjacent neutral state has completê jurišdiction over the air, and the 'practice of 'neutrals in the last war' and the provision's 'of codes and conventions since that time established the fact that the military planes of belligerents are barred from flight in neutral air. ${ }^{40}$

From the above authorities it would appear that the general rule of military necessity cannot apply where there are customary or conventional rules of international' law restricting military necessity. It would further appear that the violation of neutral air space cannot be justified on the ground of military necessity as such violation is specifically prohibited by customary and conventional international law.

2. The right to the freedom of neutral territory from belligerent use. This is the second of the fundamental rules of neutral rights. It is the right of a neutral not to have its territory used by one belligerent as a base of military operations, of recruiting, or of communication, against another belligerent. It imposes a duty on the neutral to use all the means at its disposal to prevent such use of its territory by or on behalf of one of the belligerents. ${ }^{47}$ It also imposes the duty on belligerents not to use neutral territory as a base of military, naval or air operations against other belligerents. $^{48}$

${ }^{4}$ Ibid.

- " 2 Oppenhens, op. cit. supra note 7, at 586 .

${ }^{40} 47$ Stat. 1989, Treaty Ser. No. 845, 4 Malloy's Treatises 4743 (1910).

10 7 Hackworth, op. cit. supra note 18, at 555, citing U. S. NAVAL War COLIEGe, INTERNational LAW SituatToNs 85 (1929).

${ }^{47}$ U. S. Naval War College, International Law Situatrons 87-88 (1939).

48 The Resolution of the Meeting of the Foreign Ministers of the American Republics stated that the American Republics "(a) Shall prevent their 'respective terrestrial, maritime, and aerial territories from being utilized as bases of belligerent operations." Repost of the Delegntes 54 (Dep't State Conf. SER. 44, 1940). 
The first question to be considered here is what constitutes a base of operations. In maritime warfare such a base of operations appears to be established when neutral territory affords increased strength to some unit of naval force, such as a single warship or a flotilla of warships, which is thus enabled to engage in hostilities without returning to its home port. ${ }^{49}$ In land warfare it is generally understood that a base of operations means a location which in active military operations serves as a point of departure and return, to which lines of communication are maintained, and to which the armed forces can fall back whenever there may be need for shelter, supplies, or a renewal of the operation. ${ }^{50}$ In aerial warfare a base of operations would, in the opinion of this writer, be any airfeld or air installations located in neutral territory from which air attacks could be launched by one belligerent against another and to which belligerent aircraft could return for refueling or reequipping. ${ }^{\text {5t }}$

This writer has been unable in the sources available to him to find a single case in which a neutral state has claimed damages for violation of the right to the freedom of neutral territory from belligerent use. Although it may be said that the United States was attempting to uphold this right in the Genet controversy, the record reveals that the solution was not a demand for damages but the undeclared war with France. On the other hand, there are numerous cases where belligerents have claimed damages against neutrals for failure of the neutral to protect the right. The most notable of these cases is the Alabama Claims case, settled under the terms of the Treaty of Washington of $187 x$ between the United States and Great Britain. The arbitration tribunal awarded the United States the sum of $\$ 15,500,000.00$ "as the indemnity to be paid by Great Britain to the United States, for the satisfaction of all the claims" resulting from the violations of British neutrality by the Confederate States which injured the United States.52 The award was based on the three rules which provide that a neutral government is bound:

First. To use due diligence to prevent the fitting out; arming, or equipping, within its jurisdiction, of any vessel which it has reasonable ground to believe is intended to cruise or to carry on war against a power with which it is at peace; and also to use like diligence to prevent the departure from its jurisdiction of any vessel intended to cruise or carry on war as above, such vessel having been specially adapted, in whole or in part, within such jurisdiction, to warlike use.

Secondly. Not to permit or suffer either belligerent to make use of its ports or waters as the base of naval operations against the other, or for the purpose of the renewal or augmentation of military supplies or arms, or the recruitment of men.

Thirdly. To exercise due diligence in its own ports and waters, and as to all persons within its jurisdiction, to prevent any violation of the foregoing obligations and duties. ${ }^{53}$

4 a C. C. Hyde, INTERnational Law 7í6 (2d ed. 1947).

" ${ }^{\circ}$ See Sir Alexander Cockburn's opinion in 4 Moore, Internattonal Arbitrations 4100 ( 1898 ).

${ }^{61}$ See Article I6, Draft Convention on Neutrality in Naval and Aerial Warfare, 33 AM. J. INr't L. 337 (Supp. 1939).

zo 4 Papers Relating to the Treaty of Washington 49, cited in J. B. Scott and W. H. Jaeger, Cases on International Law 897, 903 (1937); .I Malloy's Treaties. 716, 722 (1910).

"I I Malioy's Trenties 700, 703 (igro). 
While these three rules caused much discussion at the time of their promulgation, they are admitted at the present time to state the duties of neutral nations in time of war and they have been incorporated in substance into Articles 5 and 8 of the Hague Convention XIII concerning the rights and duties of neutral powers in naval war. ${ }^{54}$

Due to the continuance of the legal state of war between the allied powers and Germany and Japan, no cases have yet been adjudicated by international tribunals on claims for violations of neutral rights arising out of World War II. It is the understanding of this writer that the Italian-American Conciliation Commission established under the terms of the Italian peace treaty ${ }^{55}$ is presently meeting in Rome, but as far as is known at the present time no awards have been announced.

In conclusion this writer hopes that by considering the questions here discussed he may have aided in a small measure those persons who may have to present such claims to international tribunals in the future, and that such international tribunals, having behind them the great body of the international law of neutrality laid down by their predecessors, may follow in their legal footsteps. When all is said, the fact remains that "the decisions of International Courts and Tribunals constitute evidence of international law of a very much more persuasive and authoritative character than any other available in this sphere."

\footnotetext{
se See the cited articles. See also the note in Scotr AND JAEGER, op. cit. supra note 52, at go3.

${ }^{65}$ See Article 83 of the Treaty of Peace with Italy, Dep't State Pub. No. 2743, p. 4 r.

${ }^{56}$ See Schwarzenberger, op. cit. supra note 7, Preface $v$.
} 